proper measures, when carefully timed, reduced the menace to manageable proportions. The deterioration of strawberries has greatly concerned growers, and the discovery that the disease known as 'yellow edge' is carried by a prevalent species of aphis has added to the importance of the latter as a pest. Among glass-house troubles, the record of damage to tomato seedlings by a species of the order Symphyla during the three successive years under review is of interest. Much damage has been claimed as being due to such creatures in America in recent years, but the status of this species as a pest is not as yet universally accepted.

The report concludes with a useful bibliography of publications bearing upon the subjects dealt with.

A. D. I.

\title{
The Marine Steam Boiler
}

$I^{N}$ a recent note on "The Future of Steam Propulsion", reference was made to a paper on the relative merits of steam and oil engines for ships (NATURE, 137, 267; 1936). The subject is one of considerable importance at the present time, when a period of increased ship construction is imminent, and a new and different 'battle of the boilers' such as occurred at the time of the introduction of the water-tube boiler into H.M. Navy may be anticipated. Two papers dealing with the matter were read before the spring meeting of the Institution of Naval Architects in April last. In one of these, a "Review of the Present Position of Marine Steam Boilers", Eng.Rear-Admiral W. M. Whayman dealt with large highspeed ocean-going mail steamers and passenger liners; he holds that these services constitute practically an exclusive field for steam machinery. Asserting that oil is, at present, the only suitable fuel for such installations, he points to the fact that, where speed and passenger comfort are the main consideration, oil-fired water-tube boilers have been adopted for ocean liners in all countries, and he gives details of the boiler equipment of many well-known ships. Whereas pressures on shore approach 1,500 lb. per sq. inch at $900^{\circ} \mathrm{F}$. the tabulated figures show that $400-450 \mathrm{lb}$. per sq. in. and $650^{\circ}-740^{\circ} \mathrm{F}$. con stitute the generally accepted limits for high-class sea installations at present. It is suggested that by reason of the more severe conditions of sea service, these pressures and temperatures may be expected to remain fairly steady. It should, however, be recognized that since these special sea conditions must always exist, marine practice, while necessarily following land practice at a safe distance, will steadily advance as quickly as new methods, machinery and means of operation have been proved to be sufficiently reliable for service at sea.

The water-tube boiler, by reason of the much smaller diameters used as compared with the Scotch type, has enabled pressures to be nearly doubled, and the present tendency towards the elimination of the drum makes possible further advances in working pressures. Towards this end also the use of higher tensile alloy steels, the adoption of welding processes, the provision of air heaters, and the introduction of forced circulation, of pure feed supply and of methods of treating the steam between the turbines either by re-heating or by extraction of moisture, indicate the lines on which improvements may be anticipated.

In "Naval Water-tube Boilers", Eng.-Capt. S. R. Dight gave particulars of tests and experiments which have been carried out at the Admiralty Fuel Experimental Station, Haslar, with the object of obtaining more intimate information regarding the internal working conditions, and so enabling further improvements in efficiency and reliability to be made. Circulation was tested by means of Pitot tubes, and marked variations were noted between differently placed tubes, with occasional reversals occurring in fire-row tubes when sudden changes took place in the feed supply.

A device described as a circulation augmenter was introduced to enable the feed supply to assist circulation, and proved advantageous. The overheating of fire-row tubes, the use of air pre-heaters and of automatic feed regulators were among the subjects of test, and the general conclusion was that increase of output for the same space and weight was possible. The application of forced circulation is stated to be under consideration.

\section{Breeding of Arctic Marine Prosobranchs*}

\footnotetext{
$\mathrm{D}^{\mathrm{n}}$ R. GUNNAR THORSON accompanied the Danish Three-Year Expedition to East Greenland in 1931-34 under the leadership of Dr. Lange Koch, and made extensive and regular collections of plankton from the southern main station of Ella Island during the period from January until September 1932. Later, these samples were supplemented by others collected by a Greenlander, Benjamin Samuelsen; thus giving a whole annual cycle of East

* "Studies of the Egg-Capsules and Development of Arctic Marine Prosobranchs" by Gunnar Thorson. Treaarsexpeditionen til Christian den X's Land 1931-1934 under Ledelse af Lange Koch. Medd. om Gronland, 100, No. 5 (1935).
}

Greenland plankton. In none of these samples and in none previously examined from these regions were there any prosobranchiate gastropods. This remarkable fact was partially explained by the large number of different prosobranchiate egg capsules with big embryos in the bottom samples and dredged material.

In order to investigate further, Dr. Thorson con. tinued the collecting of gastropod egg-masses in 1932 and during the cruise of the Godthaab in the summer of 1933, and in addition examined material from other expeditions. By carefully studying the species in their various habitats and their distribution, and 
by comparing the embryos with the adults a good knowledge of the prosobranchiate fauna was obtained, with their breeding, resulting in the discovery that not one species has a pelagic larva, but all pass directly into the free bottom stage after they have reached a considerable size in their capsules. Alone of the twenty-eight Greenland molluses noted (in twenty of which the breeding is described for the first time) Acmaea rubella was found to be viviparous and hermaphrodite.

The present paper deals with the egg capsules and enclosed embryos, their breeding seasons and habitats (very characteristic in most cases). The young in the capsules were identified by comparing the shell with the apex of the adult, which is very different from the rest of the shell and gives a perfectly good clue to the embryonic period. Whenever possible the size and shape of the capsules, description of embryos, duration of embryonic state and number of embryos in each capsule are given. In many cases, especially in the large species, there are nurse eggs. In Siphocurtus about eight hundred eggs are laid in each capsule, of which usually only two develop into shelled embryos which devour the others. It is found that the number of embryonic whorls in a species is not always constant, but depends upon the conditions of nourishment in the capsules, and the time of escape of the embryos depends on the amount of nourishment.

The fact that these arctic species have no pelagic larvæ is very important, especially when we compare closely related species from Britain and elsewhere, and find that many of these have distinct veliger larvæ which often stay in the plankton until several whorls are attained. With the larger forms such as Buccinum and Neptunea, the young emerge in the crawling stage in both Arctic and British waters, but the British turrids and the species of Natica and Velutina whose larvæ are known all have welldeveloped veligers which remain in the plankton for a considerable time.

The author does not in this paper make any sug. gestions as to the special conditions in these Arctic waters which apparently prevent any pelagic prosobranch larvæ from living. One anticipates with interest a discussion on these general problems.

\section{Radio Research in Australia}

$\mathrm{I}^{\mathrm{T}}$ is with considerable satisfaction that those responsible for the organization of radio research in Great Britain will note the continued activity of the Australian Radio Research Board as shown by the seventh Annual Report for the year ended June 30, 1935, recently issued by the Commonwealth Council for Scientific and Industrial Research ${ }^{1}$. Some of the papers published during the year under review have already been noticed (NATURE, 136, 650 ; 1935) and further papers have just been issued in Report No. 9 .

Investigations connected with the fading of radio signals and the transmission of waves through the ionosphere have been continued with the aid of fresh modes of attack and advances in technique. A new method of carrying out frequency-change emissions for the recording of interference fringes at the receiving station has been developed, involving the production and separation of modulation sidebands at the transmitter. It is pointed out that one of the methods of controlling the wireless signal variations, commonly known as fading, is to emit signals simultaneously on a number of adjacent carrier frequencies; and some preliminary experiments have been carried out to ascertain the pos. sibilities of this technique as applied to radiotelephony circuits. In the field of atmospherics, observations of direction, wave form and intensity are being continued as a long-term investigation. Most of the evidence supports the now generally accepted view that every atmospheric originates in a storm centre and probably in an actual lightning flash. From the study of intensities of atmospherics from lightning at known distances, it has been estimated that the equivalent power of a lightning flash is about $2 \mathrm{kw}$. for a receiver tuned to 1,000 $\mathrm{kc} / \mathrm{sec}$. and with a band-width of $20 \mathrm{kc} . / \mathrm{s}>\mathrm{e}$.; the total peak radiated power is probably of the order of $100,000 \mathrm{kw}$. The application of the knowledge obtained in this work to interference with broadcast reception, to meteorology and particularly in reference to aircraft navigation at night, receives continuous consideration in Australia.

The Annual Report acknowledges the co-operation which the Radio Research Board has received from such institutions as the Postmaster General's Department, the Universities of Melbourne and Sydney, the Department of Defence, and the Commonwealth Solar Observatory and Meteorological Bureau. The Board also welcomes the indication of the way its staff is regarded by industry, given by the fact that two of its members have recently resigned to take up industrial appointments.

The other publication recently issued, No. 9 in the series of Reports of the Australian Radio Research Board ${ }^{2}$, contains seven papers. The first two papers deal with the study of the magneto-ionic theory of wave-propagation. A graphical method to facilitate this study, worked out by Prof. V. A. Bailey, has been applied by Dr. D. F. Martyn to the calculation of dispersion, absorption and polarisation curves for five typical wave-lengths between $100 \mathrm{~m}$. and $20,000 \mathrm{~m}$.

In the third paper, Mr. J. H. Piddington deseribes an investigation of the causes of frequency variation of a dynatron valve oscillator, and indicates the manner in which such variations may be reduced. Two of the papers by Dr. G. Builder deal with certain aspects of circuit technique as applied to radio reception, while a third describes a useful and robust thermionic voltmeter having four ranges between $0-5$ and $0-500$ volts. The last paper in the Report is by Mr. Piddington, and this describes the principles and design of a novel form of harmonic analyser, which operates by suppressing the fundamental frequency and measuring the harmonics with a cathode ray tube outfit or a thermionic voltmeter.

${ }^{1}$ Reprinted from the Journal of the Council for Scientiflc and Industrial Research, Vol. 8, No. 4, November, 1935. (Melbourne: Government Printer.

${ }^{2}$ Commonwealth of Australia : Council for Scientific and Industrial Research. Bulletin No. 95: Radio Research Board, Report No. 9. Pp. 71. (Melbourne: Government' Printer, 1936.) 